\title{
Discussion on the repeated inclusion of randomized controlled trials in meta-analysis
}

\author{
Jie Wei^ \\ Department of Hematology, People's Hospital of Baise, Baise, China \\ Correspondence to: Jie Wei, MSc. Department of Hematology, People's Hospital of Baise, Baise, China. Email: Weijie20212021@126.com. \\ Response to: Zhang Y, Song Y, Ni Q, et al. Systematic review and meta-analysis: transplanted hematopoietic stem cells and killer cells on leukemia. \\ Ann Palliat Med 2021;10:7872-83.
}

Submitted Aug 22, 2021. Accepted for publication Oct 29, 2021.

doi: 10.21037/apm-21-2344

View this article at: https://dx.doi.org/10.21037/apm-21-2344

I read an article written by Zhang et al. (1) out of interest recently, who performed a meta-analysis aimed to study the efficacy of hematopoietic stem cell transplantation (HSCT) combined with killer cells in the treatment of leukemia. The meta-analysis concluded that HSCT combined with killer cells effectively reduced the incidence of graft-versushost disease (GvHD) in patients, while it had no significant effect on overall survival and recurrence rates. I do agree the most ideas in the paper and appreciate the results of the authors' work. However, after a careful learning of the paper, I would like to raise a following suggestion.

As I known, repeatedly published studies which contained substantial overlapping data from the same patient population should be excluded in a meta-analysis (2). I have read and noticed that 2 studies in table 1, referred to Refs. 1 and 4, were with a same registration number $(3,4)$. It indicated that there is a high probability that the two papers have duplicate research participants. Therefore, I suspectted that the authors should verifiy the repeated studies and exclude one of them.

\section{Acknowledgments}

Funding: None.

\section{Footnote}

Provenance and Peer Review: This article was a standard submission to the journal. The article did not undergo external peer review.

Conflicts of Interest: The author has completed the ICMJE uniform disclosure form (available at https://dx.doi. org/10.21037/apm-21-2344). The author has no conflicts of interest to declare.

Ethical Statement: The author is accountable for all aspects of the work in ensuring that questions related to the accuracy or integrity of any part of the work are appropriately investigated and resolved.

Open Access Statement: This is an Open Access article distributed in accordance with the Creative Commons Attribution-NonCommercial-NoDerivs 4.0 International License (CC BY-NC-ND 4.0), which permits the noncommercial replication and distribution of the article with the strict proviso that no changes or edits are made and the original work is properly cited (including links to both the formal publication through the relevant DOI and the license). See: https://creativecommons.org/licenses/by-nc-nd/4.0/.

\section{References}

1. Zhang Y, Song Y, Ni Q, et al. Systematic review and metaanalysis: transplanted hematopoietic stem cells and killer cells on leukemia. Ann Palliat Med 2021;10:7872-83.

^ ORCID: 0000-0003-2164-3876. 
2. Kllén B. Drugs During Pregnancy. Cham: Springer, 2016:99-103.

3. Wang Y, Liu QF, Xu LP, et al. Haploidentical vs identicalsibling transplant for AML in remission: a multicenter, prospective study. Blood 2015;125:3956-62.

4. Chang YJ, Wang Y, Liu YR, et al. Haploidentical

Cite this article as: Wei J. Discussion on the repeated inclusion of randomized controlled trials in meta-analysis. Ann Palliat Med 2021;10(11):12046-12047. doi: 10.21037/apm-21-2344 allograft is superior to matched sibling donor allograft in eradicating pre-transplantation minimal residual disease of AML patients as determined by multiparameter flow cytometry: a retrospective and prospective analysis. J Hematol Oncol 2017;10:134. 